\title{
Stimulated growth hormone (GH) release in Friesian cattle with respect to $\mathrm{GH}$ genotypes
}

\author{
Renata Grochowska ${ }^{a *}$, Lech Zwierzchowski ${ }^{\mathrm{a}}$, \\ Marek Snochowski ${ }^{b}$, Zygmunt Reklewski ${ }^{\mathrm{a}}$

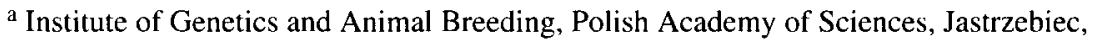 \\ 05-551 Mroków, Poland \\ ${ }^{\mathrm{b}}$ Institute of Animal Physiology and Nutrition, Polish Academy of Sciences, \\ 05-110 Jablonna, Poland
}

(Received 3 November 1998; accepted 18 February 1999)

\begin{abstract}
The effects of bovine growth hormone (GH) polymorphism at the amino acid position 127 (substitution of leucine to valine) on milk and meat production traits have been reported; however, the physiological background of this influence has not yet been recognised. The aims of this study were to estimate allele frequencies of the growth hormone gene in a population sample of Friesian cattle, and to characterise the TRH-induced GH release with respect to GH genotypes. The analysis covered data on 214 Polish Friesians, aged 11 months, used to identify GH genotypes by the PCRRFLP technique. Frequencies of leucine (Leu) and valine (Val) alleles were 0.69 and 0.31 , respectively. The GH release was analysed after thyrotropin releasing hormone (TRH) stimulation in blood samples collected over a period of $2.5 \mathrm{~h}$. There was a lack of significant difference in the overall characteristics of $\mathrm{GH}$ release in the blood of Friesian cattle with different $\mathrm{GH}$ genotypes $(P>0.05)$. Nevertheless, the $\mathrm{Val} / \mathrm{Val}$ homozygotes had higher $\mathrm{GH}$ baselines both within heifers and bulls (14.1 \pm 2.8 and $14.6 \pm 2.0 \mathrm{ng} \cdot \mathrm{mL}^{-1}$, respectively) than others. Moreover, males of the $\mathrm{Val} / \mathrm{Val}$ genotypes showed the highest peak amplitude of GH release $\left(55.5 \pm 8.1 \mathrm{ng} \cdot \mathrm{mL}^{-1}\right)$ in comparison to all other animals. The results presented provide evidence for the lack of difference in stimulated GH release with respect to GH genotypes in dairy cattle. (C) Inra/Elsevier, Paris.
\end{abstract}

gene polymorphism / hormone release / growth hormone / dairy cattle

Résumé - Stimulation de la sécrétion d'hormone de croissance (GH) chez les bovins de la race Frisonne en fonction des génotypes de GH. Les effets du polymorphisme génétique de GH bovin en position 127 d'un acide aminé (substitution de leucine par valine) sur les caractères de production laitière et de viande ont été déjà rapportés. Cependant, le fond physiologique de cette influence reste inconnu. L'objet de la présente étude était d'estimer les fréquences des allèles du gène de GH

* Correspondence and reprints

E-mail: panighz@atos.warman.com.pl 
dans la population de bovins de la race Frisonne et de caractériser la sécrétion de GH stimulée avec la thyrolibérine (TRH) en fonction des génotypes de $\mathrm{GH}$. Ce travail rapporte les résultats obtenus sur un échantillon de 214 bovins, âgés de 11 mois dont les génotypes ont été identifiés par la technique de PCR-RFLP. Les fréquences des allèles de leucine (Leu) et de valine (Val) étaient de 0,69 et 0,31, respectivement. La sécrétion de GH chez les bovins ayant recu des injections intravéneuses de TRH a été analysée dans les échantillons de sang prélevés par cathéter toutes les 15 min pendant une période de $2,5 \mathrm{~h}$. Il n'a y pas de différences significatives dans le profil général de la sécrétion de $\mathrm{GH}$ dans le sang des bovins de la race Frisonne selon les différents génotypes de GH $(p>0,05)$. Toutefois, le taux basal de $\mathrm{GH}$ chez les homozygotes pour le variant $\mathrm{Val} / \mathrm{Val}$, chez les génisses ainsi que chez les taureaux, est plus élevé $\left(14,1 \pm 2,8 \mathrm{ng} \cdot \mathrm{mL}^{-1}\right.$ et $14,6 \pm 2,0 \mathrm{ng} \cdot \mathrm{mL}^{-1}$, respectivement) par rapport aux autres animaux. De plus, les mâles $\mathrm{Val} / \mathrm{Val}$ présentaient une réponse supérieure à la stimulation de la sécrétion de $\mathrm{GH}$ (pic de sécrétion a 55,5 $\pm 8,1 \mathrm{ng} \cdot \mathrm{mL}^{-1}$ ). Ces résultats mettent en évidence l'absence de lien entre la stimulation de la sécrétion de GH et les génotypes de GH chez les bovins laitiers. () Inra/Elsevier, Paris.

polymorphisme de gène / sécrétion d'hormone / hormone de croissance / bovins laitiers

\section{INTRODUCTION}

Growth hormone $(\mathrm{GH})$ is released from the bovine pituitary as four variants composed of alanine or phenylalanine residues at the amino terminus and leucine or valine substitutions at residue 127 [2]. In the latter case, an allelic polymorphism in the $\mathrm{GH}$ gene is caused by a nucleotide change (CTG to GTG) related to the occurrence of $\mathrm{GH}$ variants with leucine (Leu) or valine ( $\mathrm{Val})$ at amino acid (a.a.) position 127 [21].

Most studies have reported a higher frequency of the Leu allele (over 0.90) compared to the Val allele in Holstein populations (e.g. [17]). The lower frequency of the Leu variant is usually presented in Friesian cattle, e.g. 0.80 in German Friesian bulls by Schlee et al. [19].

Since the growth hormone has been shown to be important for the control of growth, development of the mammary gland and lactation in cattle, the GH gene has a potential as a marker for genetic variation in milk and meat production. Lee et al. [12] found slightly greater PTAs (predicted transmitting abilities) for milk yield in Holstein cows $(N=65)$ of the Leu/Leu homozygotes compared to the Leu/Val heterozygotes $(P<0.1)$. Furthermore, Schlee et al. [20] stated that Simmental bulls $(N=203)$ with the Leu/Val genotypes were superior to the rest of the $\mathrm{GH}$ genotypes in both carcass gain and meat value $(P<0.01)$. Our previous results [24] also showed a significant relationship of the Leu allele $(P<0.01)$ with a better growing ability and feed efficiency in Polish Friesian cattle $(N=265)$.

Mutagenesis of the bovine GH gene including single amino acid substitutions (e.g. at a.a. positions 117,119 or 122) produced the GH protein showing differential biological activities. Transgenic mice generated with the mutated $\mathrm{GH}$ genes and fused to the mouse metallothionein promoter demonstrated various phenotypes ranging from dwarfism to gigantism $[3,11]$.

Synthesis of recombinant bovine $\mathrm{GH}$ variants has allowed the exploration of the effect of various amino acid substitutions on the biopotency of the GH molecule. According to the results of Eppard et al. [5] $\left[\mathrm{Ala}^{1}\right]-\mathrm{bGH}$ variants with valine at position 127 elicited a greater milk response than Leu variants even though immunoreactive GH concentrations in the blood were statistically equivalent. The explanation of the difference between $\mathrm{Val}$ and Leu variants of [Ala $\left.{ }^{1}\right]-b G H$ is, however, uncertain, considering that valine/leucine substitution did not 
affect the milk response to [Met $\left.{ }^{1}\right]$ or $\left[\mathrm{Ser}^{1}\right]$ bGH variants.

The objectives of this study were to estimate allele frequencies of the growth hormone gene at amino acid position 127 in a sample population of Polish Friesian cattle, and to characterise the $\mathrm{GH}$ release after TRH stimulation with respect to $\mathrm{GH}$ genotypes.

\section{MATERIALS AND METHODS}

\subsection{Animals}

A total of 214 Polish Friesian cattle (104 heifers and 110 bulls) of more than $50 \%$ of the Holstein breed (85 individuals with less than $74 \%$ and 129 with more than $75 \%$ ) were used. All animals originated from 29 Holstein sires, and the size of the progeny groups varied between one and 28 (with an average of 7.4 calves per sire). The heifers and bulls were born at different farms between April 1994 and April 1996 and were maintained in one local station from the age of 4 months onwards. They were fed diets twice a day at 06.00 and 16.00 hours formulated according to sex and age under a standardised feeding regime. Water was available at all times. The ration consisted of commercial concentrates (POLFARM), maize silage and hay, and was supplemented with vitamins and minerals. The metabolisable energy content (ME) per kg dry matter (DM) and crude protein (CP) were 5.3 MJ $\mathrm{ME}$ and $164.5 \mathrm{~g} \mathrm{CP}$ for concentrates, 6.4 MJ ME and $11.9 \mathrm{~g} \mathrm{CP}$ for silage, $3.3 \mathrm{MJ} \mathrm{ME}$ and $88.9 \mathrm{~g}$ $\mathrm{CP}$ for hay, respectively. The average daily live weight gain calculated over the period from birth to 11 months of age was $692 \pm 90 \mathrm{~g}$ (mean \pm SD) in heifers and $887 \pm 99 \mathrm{~g}$ in bulls.

\subsection{Blood collection and TRH treatment}

The blood samples were collected between March 1995 and February 1997. The young cattle were kept individually in tie-stalls in batches of one to six animals of similar age $(335 \pm$ 8 days). The blood was sampled through catheters (Viggo-Spectramed Secalon 16G 42 CM, Seldy, UK) inserted into the jugular vein on the day before testing. All samples were drawn into heparinised tubes (9-mL Vacuette Greiner Labor- technik, Germany). Plasma was harvested by centrifugation $\left(4^{\circ} \mathrm{C}, 2000 \mathrm{~g}, 20 \mathrm{~min}\right)$ and stored at $-20^{\circ} \mathrm{C}$ until assayed for $\mathrm{GH}$ concentration.

As GH is secreted in a pulsatile manner [1], thyrotropin releasing hormone (TRH) was used to induce $\mathrm{GH}$ release following the procedure described by Lovendahl and Sejrsen [13]. Eleven serial blood samples were collected per animal at 15 -min intervals. The single infusion of synthetic bovine TRH (Sigma Chemical Co., SigmaAldrich, Inc.) was prepared individually for each animal $\left(0.15 \mu \mathrm{g} \cdot \mathrm{kg}^{-1}\right.$ body weight, dissolved in $0.9 \% \mathrm{NaCl}$ in an injection volume of $10 \mathrm{~mL}$ ) and administrated immediately after the second blood sample. The cattle were weighed on the day before cannulation to calculate doses of TRH. The live weights of heifers and bulls were 269.9 $\pm 29.8 \mathrm{~kg}$ (range $165-360$ ) and $336.2 \pm 35.0 \mathrm{~kg}$ (range 258-414), respectively.

\subsection{Genotyping and GH determination}

DNA was isolated from the blood collected on K-EDTA. The isolation of DNA was performed with the rapid method described by Kawasaki [8]. The identification of the GH genotype was performed with the PCR-RFLP method according to Lucy et al. [15]. The 428-bp fragment of the GH gene was amplified, including intron IV and parts of exons IV and V. The sequences of the primers were:

5'-CCGTGTCTATGAGAAGC-3' and 5'-GTTCTTGAGCAGCGCGT-3'. Thirty amplification cycles included: $94{ }^{\circ} \mathrm{C}-30 \mathrm{~s} ; 60{ }^{\circ} \mathrm{C}$ $-1 \min ; 72{ }^{\circ} \mathrm{C}-30 \mathrm{~s}$. The amplified DNA was digested with the AluI restriction nuclease (Gibco BRL; $3 \mathrm{~h}, 10$ units $/ 20 \mu \mathrm{L}, 37^{\circ} \mathrm{C}$ ) and analysed on $2 \%$ agarose gel in TBE buffer.

Bovine growth hormone concentrations were determined in the blood plasma samples $(100 \mu \mathrm{L})$ using the double antibody radioimmunoassay described by Dvorak et al. [4], and the antibodies were kindly supplied by these authors. The recombinant bovine GH (Monsanto, USA) was used as a tracer and standard. The working range of the calibration curve was from 0.06 to $8.0 \mathrm{ng} /$ tube. The coefficients of variation (CV) calculated for control samples at the concentrations of $0.1,0.8$ and $6.4 \mathrm{ng} /$ tube of $\mathrm{GH}$ were 7.4 , 2.6 and $5.5 \%$, respectively. All plasma samples were analysed in duplicate in two-fold dilutions. Samples lying outside the reliable range of the calibration curve were analysed again as undi- 
luted or five-fold diluted, respectively. The interassay coefficient of variation was $14 \%$.

\subsection{Statistical analysis}

In the primary analysis the single peak evaluation was used to asses the GH baseline (the samples were collected at $-15 \mathrm{~min}$ and from 75 to $135 \mathrm{~min}$ ), and the $\mathrm{GH}$ response was calculated from the area under the curve (sum of the trapezoid areas between the curve and abscissa) at 15,30 and 45 min following TRH. The PULSAR program developed by Merriam and Wachter [16] was also applied independently. The cut-off parameters for $\mathrm{G}(\mathrm{n})$ were settled to a $5 \%$ error rate assuming normal distribution of the data. Since the results in both methods were similar, the PULSAR parameters were used for the final presentation. The baseline and the peak amplitude of TRH-induced GH release was considered in a statistical evaluation. The ratio of peak amplitude to baseline less than or equal to 1, was used as a selection criterion for non-responding animals.

The calculation of allele frequencies of the bovine growth hormone was based on the direct allele counting method [7]. To asses the probability of significance the Chi-square test was used. The effects of GH genotypes on TRHinduced GH release were analysed by the GLM procedure of the SAS program [18] with the following sire model:

$$
\begin{aligned}
y_{i j k l m}=\mu & + \text { gene }_{i}+\operatorname{sex}_{j}+\text { gene }_{i} \times \text { sex }_{j} \\
& + \text { SY }_{k}+\operatorname{sire}_{\mathrm{l}}+\mathrm{e}_{\mathrm{ijklm}}
\end{aligned}
$$

where $y_{i j k l m}$ is observation, $\mu$ is the population mean, gene ${ }_{i}$ is the fixed effect of the $\mathrm{GH}$ genotype of the animal $(i=\mathrm{Leu} / \mathrm{Leu}, \mathrm{Leu} / \mathrm{Val}$, Val/Val), sex $x_{j}$ is the fixed effect of sex of the animal $(j=1,2)$, gene $_{i} \times$ sex $_{j}$ is the interaction effect specific to the GH genotype and sex of the animal, $S_{k}$ is the fixed effect of season-year class of blood sampling $(k=1, \ldots, 7)$, sire sis $_{1}$ the random effect of the sire $(l=1, \ldots, 29), e_{i j k l m}$ is the random residual effect.

A total of seven SY classes were fitted in the model with four seasons (December-February, March-May, June-August, SeptemberNovember) and two years of sampling (1995 and 1996).

\section{RESULTS}

Figure 1 shows a representative RFLP polymorphism analysis in the bovine $\mathrm{GH}$ gene. As expected, the polymerase chain reaction yielded a 428 -bp amplification product. AluI restriction enzyme digestion produced 265-, 96- and 51-bp fragments for the Leu variant and 265- and 147-bp fragments for the Val variant (the 16-bp fragment was not visible with ethidium bromide staining). The Leu/Val heterozygotes showed 265-, 147-, 96- and 51-bp AluI restriction fragments.

The bovine growth hormone allele frequencies in the investigated sample of the Polish Friesian cattle are given in table $I$. The frequencies of the Leu and Val alleles

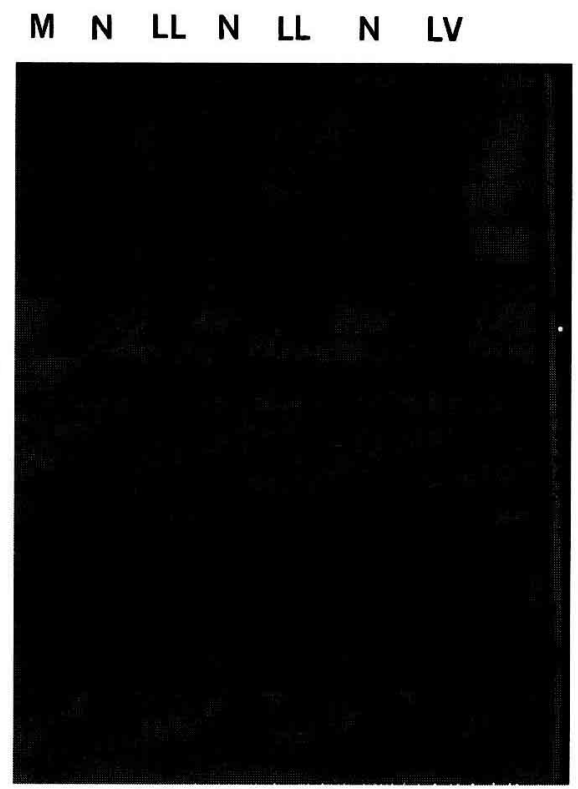

\section{$N \quad V V \quad N \quad L V \quad N \quad L V \quad N \quad L V$}

Figure 1. Ethidium bromide-stained agarose showing RFLP polymorphism detected after AluI digestion of 428-bp fragment of bovine $\mathrm{GH}$ gene. M: DNA size marker (1-kb DNA ladder, Gibco, BRL); N: non-digested 428-bp amplification product; LL, LV and VV: Leu/Leu, Leu/Val and $\mathrm{Val} / \mathrm{Val}$ genotypes, respectively. 
Table I. Observed (OBS) and expected (EXP) numbers of GH genotypes and allele frequencies in a sample of Polish Friesian cattle.

\begin{tabular}{|c|c|c|c|c|c|}
\hline \multirow[t]{2}{*}{ Item } & \multicolumn{3}{|c|}{ Genotypes } & \multicolumn{2}{|c|}{ Allele frequencies } \\
\hline & Leu/Leu & Leu/Val & $\mathrm{Val} / \mathrm{Val}$ & Leu & Val \\
\hline $\begin{array}{l}\text { Heifers } \\
\text { Obs. } \\
\text { Exp. } \\
\chi^{2}=0.80\end{array}$ & $\begin{array}{l}58 \\
56.95\end{array}$ & $\begin{array}{l}37 \\
40.02\end{array}$ & $\begin{array}{l}9 \\
7.03\end{array}$ & 0.74 & 0.26 \\
\hline $\begin{array}{l}\text { Bulls } \\
\text { Obs. } \\
\text { Exp. } \\
\chi^{2}=4.72\end{array}$ & $\begin{array}{l}51 \\
46.48\end{array}$ & $\begin{array}{l}40 \\
50.05\end{array}$ & $\begin{array}{l}19 \\
13.48\end{array}$ & 0.65 & 0.35 \\
\hline $\begin{array}{c}\text { Total } \\
\text { Obs. } \\
\text { Exp. } \\
\chi^{2}=5.49\end{array}$ & $\begin{array}{l}109 \\
101.89\end{array}$ & $\begin{array}{l}77 \\
91.55\end{array}$ & $\begin{array}{l}28 \\
20.57\end{array}$ & 0.69 & 0.31 \\
\hline
\end{tabular}

Figure 2. Examples of individual changes in GH concentration in the peripheral blood plasma of Friesian heifers (F) and bulls (M) following single TRH injection $\left(0.15 \mu \mathrm{g} \cdot \mathrm{kg}^{-1}\right.$ body weight at time $=0$ ).

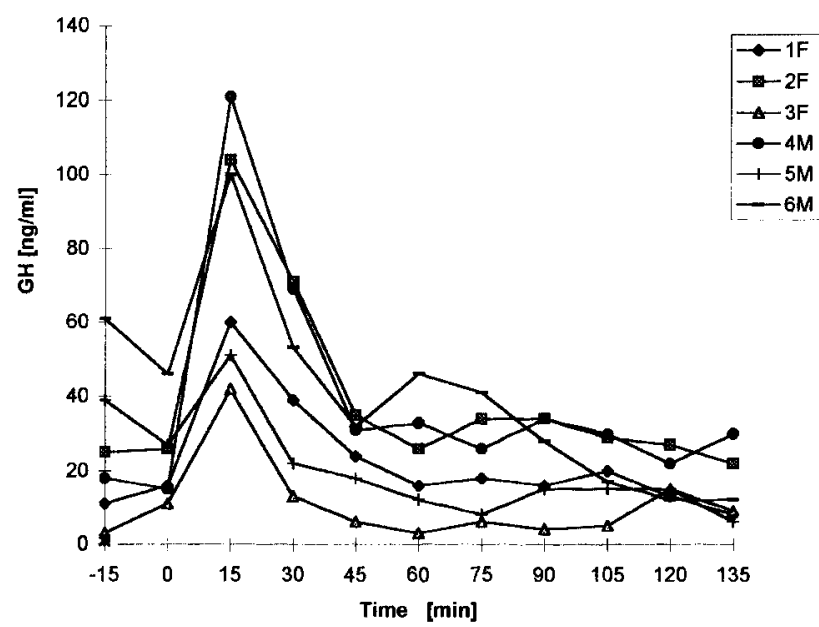

fered significantly $\left(\chi^{2}=4.72\right)$ as well as those in the whole sample tested $\left(\chi^{2}=5.49\right)$.

The typical changes in GH concentrations following TRH stimulation are shown in figure 2. The ratio of peak amplitude to baseline, equal or lower than 1 was found in 23 heifers and ten bulls (15\% of the total population). Therefore, those animals were classified as non-responders and were evenly distributed among genotypes. 
Table II. ANOVA table with mean sum of squares for GH genotype, sex, interaction of genotype by sex and season by year, sire, the residual and R-square for TRH-induced GH release in Friesian cattle.

TRH-induced GH release

\begin{tabular}{lcccc} 
Source of variation & DF & $\begin{array}{c}\text { Baseline } \\
\text { mean square }\end{array}$ & DF & $\begin{array}{c}\text { Peak amplitude } \\
\text { mean square }\end{array}$ \\
\hline GH genotype & 2 & 54.5 & 2 & 226.8 \\
Sex & 1 & 66.1 & 1 & $12032.3^{* * *}$ \\
GH genotype $\times$ sex & 2 & 12.4 & 2 & 682.8 \\
Season $\times$ Year & 7 & 75.1 & 6 & $1896.2^{* *}$ \\
Sire & 28 & $99.1 *$ & 26 & 1029.6 \\
Residual & 173 & 58.0 & 161 & 772.1 \\
R-square & & 0.35 & & 0.37 \\
\hline
\end{tabular}

$* P<0.05 ; * * P<0.01 ; * * * P<0.001$. DF: degrees of freedom.

The models explained $35-37 \%$ of the total variation in the $\mathrm{GH}$ parameters, as presented by the R-square values in table $I I$. The effects of sex $(P<0.001)$ and season $\times$ year of blood sampling $(P<0.01)$ were the major sources of variation in the peak amplitude. The sire had a significant effect on the $\mathrm{GH}$ baseline concentration $(P<0.05)$, and was also close to significance for peak amplitude $(P=0.09)$. There was no influence of GH genotypes on TRH-induced GH release $(P>0.05)$. Moreover, gene and sex interaction did not have any impact on the analysed GH variables.

The seasonal differences in GH release after TRH stimulation among Friesian cattle of various GH genotypes are given in table III. The highest value of the GH baseline was observed in Val/Val homozygotes during autumn $\left(17.4 \pm 3.4 \mathrm{ng} \cdot \mathrm{mL}^{-1}\right)$, while the lowest one was found in the Leu/Leu homozygotes during spring $\left(7.7 \pm 2.6 \mathrm{ng} \cdot \mathrm{mL}^{-1}\right)$. The seasonal differences in GH peak amplitude among GH genotypes seemed to be less clear. It is interesting to note, however, that the highest figures of peak amplitude were demonstrated for the Leu/Leu and the Val/ Val homozygotes and for the Leu/Val heterozygotes from March to May $(69.3 \pm 12.8$, $70.5 \pm 11.8,74.8 \pm 16.4 \mathrm{ng} \cdot \mathrm{mL}^{-1}$, respectively).
Table IV presents least-square means and standard errors for the effect of the $\mathrm{GH}$ genotype on TRH-induced GH release in both sexes. As shown, the $\mathrm{GH}$ baseline was found to be higher in bulls than in heifers; however, the differences were not statistically significant $(P>0.05)$. It might be stressed that the Val/Val homozygotes had the highest baseline for both females and males $\left(14.1 \pm 2.8\right.$ and $14.6 \pm 2.0 \mathrm{ng} \cdot \mathrm{mL}^{-1}$, respectively). Furthermore, bulls reached a higher $\mathrm{GH}$ peak amplitude than heifers $(P<0.01)$. Interestingly, males with the $\mathrm{Val} / \mathrm{Val}$ genotype had a higher peak amplitude $\left(55.5 \pm 8.1 \mathrm{ng} \cdot \mathrm{mL}^{-1}\right)$ than all other animals.

\section{DISCUSSION}

For the first time, the stimulated GH release in a large population of Friesian cattle was described with respect to $\mathrm{GH}$ genotypes. The results of the study also provide information on allele frequencies, which would be required to infer the effect of a single gene for selection procedures.

The values in the present study regarding the Leu and Val allele frequencies corresponded well with the results of Zwierzchowski et al. [23] obtained for the same 
Table III. Least square means (LSM) and standard errors (SE) for the effect of GH genotypes on TRHinduced GH release in peripheral blood plasma of Friesian cattle with respect to seasons.

\begin{tabular}{|c|c|c|c|c|}
\hline \multirow{3}{*}{ GH genotypes } & \multicolumn{4}{|c|}{ TRH-induced GH release } \\
\hline & \multicolumn{2}{|c|}{ Baseline } & \multicolumn{2}{|c|}{ Peak amplitude } \\
\hline & LSM & SE & LSM & SE \\
\hline \multicolumn{5}{|l|}{ Leu/Leu: } \\
\hline Dec-Feb & 12.8 & 2.3 & $29.9^{A}$ & 8.2 \\
\hline Mar-May & $7.7^{\mathrm{A}}$ & 2.6 & $69.3^{\mathrm{B}}$ & 12.8 \\
\hline Jun-Aug & $15.1^{\mathrm{B}}$ & 1.8 & $44.5^{\mathrm{A}}$ & 6.6 \\
\hline Sep-Nov & 13.7 & 1.9 & $35.8^{\mathrm{A}}$ & 7.4 \\
\hline \multicolumn{5}{|l|}{ Leu/Val: } \\
\hline Dec-Feb & 12.8 & 2.6 & $24.1^{\mathrm{A}}$ & 9.4 \\
\hline Mar-May & 12.1 & 2.6 & $70.5^{\mathrm{B}}$ & 11.8 \\
\hline Jun-Aug & 13.1 & 2.1 & $39.9^{\mathrm{A}}$ & 7.5 \\
\hline Sep-Nov & 11.9 & 2.4 & $28.8^{\mathrm{A}}$ & 8.5 \\
\hline \multicolumn{5}{|l|}{ Val/Nal: } \\
\hline Dec-Feb & 13.8 & 4.4 & $43.1^{\mathrm{A}}$ & 18.3 \\
\hline Mar-May & 13.1 & 4.0 & $74.8^{\mathrm{B}}$ & 16.4 \\
\hline Jun-Aug & 14.3 & 2.7 & $52.8^{\mathrm{B}}$ & 9.9 \\
\hline Sep-Nov & $17.4^{\mathrm{B}}$ & 3.4 & $18.1^{\mathrm{A}}$ & 13.1 \\
\hline
\end{tabular}

Different superscripts in column indicate the level of significance for differences at $P<0.01$.

Table IV. Least square means (LSM) and standard errors (SE) for the effect of GH genotypes on TRHinduced $\mathrm{GH}$ release in peripheral blood plasma of Friesian heifers and bulls.

\begin{tabular}{|c|c|c|c|c|}
\hline \multirow{3}{*}{ GH genotypes } & \multicolumn{4}{|c|}{ TRH-induced GH release } \\
\hline & \multicolumn{2}{|c|}{ Baseline } & \multicolumn{2}{|c|}{ Peak amplitude } \\
\hline & LSM & SE & LSM & $\mathrm{SE}$ \\
\hline \multicolumn{5}{|l|}{ Heifers: } \\
\hline Leu/Leu & 11.0 & 1.4 & $29.3^{A}$ & 5.5 \\
\hline Leu/Val & 10.9 & 1.5 & $23.1^{\mathrm{A}}$ & 5.7 \\
\hline $\mathrm{Val} / \mathrm{Val}$ & 14.1 & 2.8 & $23.7^{\mathrm{A}}$ & 10.2 \\
\hline \multicolumn{5}{|l|}{ Bulls: } \\
\hline Leu/Leu & 12.5 & 1.4 & $43.8^{\mathrm{B}}$ & 5.9 \\
\hline Leu/Val & 13.6 & 1.5 & $45.5^{\mathrm{B}}$ & 5.8 \\
\hline $\mathrm{Val} / \mathrm{Val}$ & 14.6 & 2.0 & $55.5^{\mathrm{B}}$ & 8.1 \\
\hline
\end{tabular}

Different superscripts in column indicate the level of significance for differences at $P<0.01$. 
breed of cattle. It should be emphasised that the Polish Friesian cattle is a dual purpose population with a high proportion of the Holstein breed used to improve milk production. The estimates reported by Van der Werf et al. [22] were higher for the Leu allele in Holsteins (0.93 in cows and 0.96 in bulls) compared to Polish Friesians. Perhaps, the frequency of the Leu allele increases in a parallel manner with the increasing proportion of the Holstein genotype.

According to the Hardy-Weinberg law, the sampled population of Polish Friesian cattle showed no equilibrium in relation to the GH gene. The discrepancy might possibly have been due to non-random mating of the parents. As shown, the impact among the progeny on the genotypic frequencies was to increase the frequencies of the Leu/Leu homozygotes and to reduce those of the Leu/Val heterozygotes. Assuming desirable associations between the Leu allele and milk traits, it seems to be obvious that the currently practised selection has an indirect impact on the high frequency of the Leu allele in high yielding cattle.

Our results provide evidence for the lack of difference in GH release after TRH stimulation with respect to $\mathrm{GH}$ genotypes in Friesian cattle. Although the studied traits had large variation coefficients $(61.5 \%$ in the baseline and $61.4 \%$ in the peak amplitude), it could be concluded that the experiment presented was large enough to reject the hypothesis of the Leu/Val polymorphism having a large impact on GH release. Large differences are needed, not only to give sufficient power to an experiment of this size, but also to make the use of such differences worthwhile (e.g. in selection).

The season of blood sampling appears to be one of the most important sources of variation in TRH-induced GH release $(P<0.01)$. The significant differences in the PULSAR parameters during different seasons were also found by Kazmer et al. [10] in young AI Holstein bulls. They reported the highest figures of $\mathrm{GH}$ baseline during autumn
$(P<0.001)$. It seems to be clear that a choice of the best season in assessing genetic merit for production traits is difficult owing to the pulsatile manner of GH release. Moreover, seasonal effects and the age of the animal tested could have been confounded.

In the present study, the GH variables were also influenced by sex: the GH peak amplitude $(P<0.01)$ was superior in bulls than in heifers. Similarly, Lovendahl and Sejrsen [13] observed a higher GH response to TRH in 10-month-old bulls than in heifers of the same age $(P<0.001)$. According to another study by Lovendahl et al. [14], 4-month-old females responded more in GH release than males after TRH stimulation $(P>0.01)$. These results have given an indication that the $\mathrm{GH}$ response to $\mathrm{TRH}$ is greater in heifers before puberty, and in males following puberty.

Our initial hypothesis was that differences in amino acid composition may lead to different biological effects and may subsequently alter growth and lactation in cattle. Therefore, the characteristics of $\mathrm{GH}$ release for individuals with various GH genotypes were essential. Although a lack of significant effects of the Leu/Val polymorphism on $\mathrm{GH}$ release was observed in this study, some differences in $\mathrm{GH}$ variables between animals of different GH genotypes were found. As shown, bulls of the Val/Val genotypes had higher GH baselines and peak amplitudes than others.

The effects found were in line with those from the recombinant bGH efficacy study of Eppard et al. [6]. Moreover, an association of the Val allele with milk production ability was suggested by Sabour and Lin [17] on the basis of an evaluation of 100 Holstein bulls.

On the contrary, the results of Schlee et al. [19] indicated a significant relationship of the Leu allele with higher GH concentrations in the blood. It has been a consistent finding of studies both within and between breeds that genetically high yielding cows have greater circulating concentrations of 
GH during lactation (e.g. [9]). Thus, it would be of great interest to verify our material during the lactation period.

Finally, the study described the characteristics of GH release in a sampled population of Friesian cattle with respect to $\mathrm{GH}$ genotypes. Moreover, allele frequencies of the $\mathrm{GH}$ gene at amino acid position 127 were estimated. In conclusion, these results provide evidence for the lack of difference in stimulated $\mathrm{GH}$ release with respect to $\mathrm{GH}$ genotypes in dairy cattle.

\section{ACKNOWLEDGEMENTS}

The authors express their appreciation to Mrs. J. Oprzadek and Mr. Z. Kolodziejski for their excellent help in collecting blood samples from animals. The work was supported by a grant (no. 5 PO6D 01109) from the State Committee for Scientific Research.

\section{REFERENCES}

[1] Anfinson M.S., Davis S.L., Christian E., Everson D.O., Episodic secretion of growth hormone in steers and bulls: An analysis of frequency and magnitude of secretory spikes occurring in a 24 hour period, Proc. Western Section, Am. Soc. Anim. Sci., 26 (1975) 175-177.

[2] Charrier J., Martal J., Growth hormone. I. Polymorphism. (Minireview), Reprod. Nutr. Dev. 29 (1988) 1-25.

[3] Chen W.Y., Wight D.C., Chen N.Y., Colmant T.C. Wagner T.E., Expression of a mutated bovine growth hormone gene suppresses growth of transgenic mice, Proc. Nat. Acad. Sci. USA 87 (1990) 5061-5065.

[4] Dvorak P., Becka S., Krejci P., Chrpova M. Radioimmunoassay of bovine growth hormone, Biochem. Radioanal. Lett. 34 (1978) 155-160.

[5] Eppard P.J., Bentle L.A., Violand B.N., Ganguli S. Hintz R.L. Kung L.Jr, Krivi G.G., Lanza G.M., Comparison of the galactopoietic response to pituitary-derived and recombinant-derived variants of bovine growth hormone, J. Endocrinol. 132 (1992) 47-56.

[6] Eppard P.J., White T.C., Birmingham B.K., Hintz R.L., Bentle L.A., Wood D.C., Salsgiver W.J., Rowold E., Miller M.A., Ganguli S., Hale M.D., Krivi G.G., Collier R.J., Lanza G.M., Pharmacokinetic and galactopoietic response to recombinant variants of bovine growth hormone, J. Endocrinol. 139 (1993) 441-450.
[7] Falconer D.S., Introduction to Quantitative Genetics, 2nd ed., Longman Group UK Ltd, Essex, UK, 1981.

[8] Kawasaki E.S., Sample preparation from blood, cells and others fluids, in: Innis M.A., Gelfand D.H., Sninsky J.J., White T.J. (Eds.), PCR Protocols: A Guide to Methods and Application, Academic Press, New York, 1990, pp 3-12.

[9] Kazmer G.W., Barnes M.A., Akers R.M., Pearson R.E., Effect of genetic selection for milk yield and increased milking frequency on plasma growth hormone and prolactin concentration in Holstein cows, J. Anim. Sci. 63 (1986) 1220-1227.

[10] Kazmer G.W., Canfield R.W., Bean B., Characteristics of somatotropin and prolactin profiles in young dairy sires before and after a 72hour fast during different seasons, J. Anim. Sci. 70 (1992) 503-507.

[11] Kopchick J.J., McAndrew S.J., Shafer A.W., Okada S., Chen X.Z., Chen W.Y., Growth hormone structure/function studies employing transgenic mice, Anim. Sci. Papers Rep. 11 (1993) 91-94.

[12] Lee B.K., Lin G.F., Crooker B.A., Murtaugh M.P., Hansen L.B., Chester-Jones H., Association of somatotropin (bST) gene polymorphism with selection for milk yield in Holstein cows, J. Dairy Sci. 76 (1993) Suppl. 1., Abstracts, 149.

[13] Lovendah] P., Sejrsen K., Endogenous growth hormone release in calves selected for milk fat yield, Anim. Prod. 56 (1993) 285-291.

[14] Lovendahl P., Angus K.B., Woolliams J.H., The effect of genetic selection for milk yield on the response to growth hormone secretagoues in immature cattle, J. Endocrinol. 128 (1991) 419-424.

[15] Lucy M.C., Hauser S.D., Eppard P.J., Krivi G.G., Clark J.H., Bauman D.E., Collier R.J., Variants of somatotropin in cattle: gene frequencies in major dairy breeds and associated milk production, Dom. Anim. Endocrinol. 10 (1993) 325-333.

[16] Merriam G.R., Wachter K.W., Algorithms for the study of episodic hormone secretion, Am. J. Physiol. 243 (1982) E310-E318.

[17] Sabour M.P., Lin C.Y., Association of bovine growth hormone genetic variants with milk production traits in Holstein cattle, XXVth International Conference on Animal Genetics, 21-25 July, Tours, France, Abstracts, 1996, p. 167.

[18] SAS, SAS/STAT User's Guide, 4th ed., Version 6, Vol. 2, SAS Institute Inc., Cary, NC, USA, 1989.

[19] Schlee P., Graml R., Schallenberger E., Schams D., Rottmann O., Olbrich-Bludau A., Pirchner F., Growth hormone and insulin-like growth factor I concentrations in bulls of various growth hormone genotypes, Theor. Appl. Genet. 88 (1994) 497-500. 
[20] Schlee P., Graml R., Rottmann O., Pirchner F., Influence of growth hormone genotypes on breeding values of Simmental bulls, J. Anim. Breed. Genet. 111 (1994) 253-256.

[21] Seavey B.K., Singh R.N.P., Lewis U.J., Geschwind I.I., Bovine growth hormone: evidence for two allelic forms, Biochem. Biophys. Res. Comm. 43 (1971) 189-195.

[22] Van der Werf J.H.J., Verburg F., Garssen G.J., Evidence for a strong effect of the Alu-I polymorphism in the growth hormone gene on yield characteristics in dairy cattle, 47 th Meeting
EAAP, 25-29 August, Lillehammer, Norway, Abstract no. 1, 1996, p. 310.

[23] Zwierzchowski L., Zelazowska B., Grochowska R., Genotyping of kappa-casein and growth hormone alleles in Polish Black and White and Piemontese cattle using PCR - RFLP technique, Anim. Sci. Papers Rep. 13 (1995) 13-20.

[24] Zwierzchowski L., Dymnicki E., Lukaszewicz M., Grochowska R., Oprzadek J., Association of growth hormone polymorphism, growth performance and feed intake parameters in Blackand-White cattle, Prace i Materialy Zootechniczne 51 (1997) 43-50. 